\title{
Über die WTO hinaus - Eckpunkte einer zukunftsfähigen Handelsordnung nach Corona
}

Die Welthandelsorganisation (WTO) mit ihren Aufgaben, Handelshemmnisse abzubauen, den internationalen Handel zu liberalisieren und Handelskonflikte zu schlichten, ist stark angeschlagen. In der 25-jährigen Geschichte der Organisation kam es trotz Regelgleichheit zu unterschiedlich erfolgreichen Ländergruppen. Die Schwellen- und Industrieländer zählen zu den Gewinnern, die zudem seit der Finanzkrise 2008 immer stärkere protektionistische Tendenzen aufweisen. Die Corona-Krise verschärft diese Tendenzen noch. Multilaterale Abkommen gewinnen zunehmend an Bedeutung. Wichtig ist es, dass Europa seine strukturellen Schwächen abbaut und seine Verhandlungsposition gegenüber China und den USA stärkt.

WTO-Reform: Formale Regelgleichheit reicht nicht aus, alle Mitgliedsländer brauchen gleiche wirtschaftliche Chancen

Martin Klein, Martin-Luther-Universität Halle-Wittenberg.

Multilaterale Abkommen: Enthusiasmus und Enttäuschung

Galina Kolev, Institut der deutschen Wirtschaft, Köln; Hochschule RheinMain, Wiesbaden.

Jürgen Matthes, Institut der deutschen Wirtschaft, Köln.

Globale Handelsordnung - mit den oder ohne die USA?

Berend Diekmann, Bundesministerium für Wirtschaft und Energie, Berlin.

Institutionelle Aspekte einer neuen Handelsordnung

Niclas Frederic Poitiers, Bruegel, Belgien.

WTO - die Hüterin des Welthandels in der Krise

Stormy-Annika Mildner, Bundesverband der deutschen Industrie, Berlin; Hertie School of Governance, Berlin.

Eckart von Unger, Bundesverband der deutschen Industrie, Berlin.

Katherine Tepper, Bundesverband der deutschen Industrie, Berlin.

Plädoyer für eine inklusive Welthandelsordnung

Christoph Scherrer, Universität Kassel.

Welthandel post Coronam

Gabriel Felbermayr, Institut für Weltwirtschaft, Kiel; Christian-Albrechts-Universität Kiel.

Title: Beyond the WTO - Cornerstones of a Sustainable Trade Order after Corona

Abstract: The World Trade Organization (WTO), with its tasks of dismantling trade barriers, liberalising international trade and settling trade disputes, has been badly hit. The organisation's 25-year history has led to countries with varying degrees of success despite identical rules. The emerging and industrialised countries who have shown ever stronger protectionist tendencies since the financial crisis of 2008 are among the winners. The Corona crisis has exacerbated these tendencies. Multilateral agreements are becoming more meaningful. It is important for Europe to reduce its structural weaknesses and strengthen its negotiating position vis-à-vis China and the USA.

JEL Classification: F10, F55, F60 